\title{
IMPLEMENTASI FUZZY LOGIC CONTROLLER UNTUK MENGATUR PH NUTRISI PADA SISTEM HIDROPONIK NUTRIENT FILM TECHNIQUE (NFT)
}

\author{
Dian Pancawati* dan Andik Yulianto \\ Program Studi Teknik Elektro, Fakultas Teknologi Industri, Universitas Internasional Batam \\ *Coresponding author, email: dianpancawati09@gmail.com
}

\begin{abstract}
Abstrak - Salah satu solusi terhadap permasalahan keterbasatan lahan dalam bercocok tanam adalah menerapkan metode hidroponik Nutrient Film Technique (NFT). Metode ini memiliki kelebihan yaitu memanfaatkan air yang tersirkulasi sebagai media tanam agar memperoleh air, nutrisi dan oksigen sehingga mampu mempercepat pertumbuhan tanaman dengan hasil yang baik. Salah satu parameter terpenting dari metode ini adalah mempertahankan $\mathrm{pH}$ nutrisi yang dipantau secara berkala. Artikel ini membahas tentang bagaimana merancang sistem kontrol pH nutrisi otomatis dengan menerapkan metode Fuzzy Logic Controller. Adapun sistem kontrol yang digunakan adalah Arduino Mega2560 dengan Analog pH Meter Kit sebagai masukan, serta solenoid valve sebagai aktuator pada sistem kontrol tersebut. Performasi respon sistem terbaik dari implementasi Fuzzy Logic Controller terdapat pada sistem yang memiliki 25 aturan. Dihasilkan rise time 1200 milisecond dan time settling pada waktu ke 5530 milisecond untuk menaikkan $\mathrm{pH}$. Sedangkan untuk menurunkan $\mathrm{pH}$, respon sistem menunjukkan rise time pada waktu 2000 milisecond dan time settling pada waktu 3000 milisecond. Sistem mampu mempertahankan pH sebesar 5,5 dengan hasil pertumbuhan selada setinggi $20 \mathrm{~cm}$ dan banyak daun 7 helai selama 54 hari.
\end{abstract}

Kata Kunci : Fuzzy Logic Controller, Hidroponik, Nutrient Film Technique.

\begin{abstract}
One solution to solve limited agricultural land is applying hydroponics Nutrient Film Technique (NFT). The advantage of NFT is using water circulated as a growing medium in order to obtain water, nutrients and oxygen to accelerate the growth of plants with good results. The most important parameter is the $\mathrm{pH}$ of nutrients. This article discusses how to design an automatic nutritional $\mathrm{pH}$ control system by implementing the method of Fuzzy Logic Controller. The control system use Arduino Mega2560, Analog pH Meter Kit as input, and the solenoid valve as actuators. The best response of the implementation of Fuzzy Logic Controller with the system which has 25 rules. The response shows that the system has in 1200 millisecond rise time and the steady state in 5530 milliseconds to increase the $\mathrm{pH}$. While to decrease the $\mathrm{pH}$ system has response of rise time at 2000 milliseconds and steady state at the time of 3000 milliseconds. The system is able to maintain the $\mathrm{pH}$ at 5.5, with the result of the growth of lettuce as high as $20 \mathrm{~cm}$ and seven leaves for 54 days.
\end{abstract}

Keywords : Fuzzy Logic Controller, Hydroponic, Nutrient Film Technique.

Copyright $@ 2016$ JNTE. All rights reserved

\section{PENDAHULUAN}

Dewasa ini ilmu pada bidang pertanian berkembang pesat, hal ini dikarenakan keterbatasan lahan pertanian, sehingga muncul inovasi-inovasi yang lebih efisien untuk mengembangkan bidang pertanian. Salah satu perkembangan tersebut yaitu metode pertanian yang baru seperti budidaya sistem hidroponik. Hidroponik sangat cocok diterapkan pada daerah yang mengalami keterbatasan lahan cocok tanam.

Salah satu sistem hidroponik yang sering digunakan adalah Nutrient Film Technique (NFT) yaitu metode budidaya tanaman dimana akar tanaman tumbuh pada lapisan nutrisi yang dangkal dan tersirkulasi sehingga memungkinkan tanaman memperoleh air, nutrisi dan oksigen [1]. NFT (Nutrient Film Technique) merupakan jenis hidroponik yang berbeda dengan hidroponik substrat. Pada NFT air bersirkulasi selama 24 jam terus-menerus agar perakaran selalu mendapatkan air nutrisi sehingga memberikan limpahan oksigen kepada akar tanaman sehingga baik untuk pertumbuhan tanaman.

Nutrisi yang diberikan pada tanaman erat 
kaitannya dengan derajat keasaman $(\mathrm{pH})$ air, di mana $\mathrm{pH}$ air akan mempengaruhi daya larut unsur hara pada tanaman yang berakibat pada kualitas kesuburan tumbuh dan kembang tanaman tersebut. Pada kenyataannya nilai $\mathrm{pH}$ nutrisi dalam tangki selalu berubah disebabkan berbagai faktor seperti media tanam [2], proses fotosintesis dan respirasi, maupun bakteri [3]. Dengan demikian, nilai $\mathrm{pH}$ perlu diupayakan bertahan pada nilai 5,5 - 6,5 menyesuaikan dengan tanaman yang dibudidayakan [4].

Pengembangan sistem kontrol nutrisi pada hidroponik telah dikembangkan seperti pada [5, $6,7,8,9]$. Berbagai metode kontrol digunakan pada teknik pengendaliannya, seperti kontrol PID (Proportional Integral Derivative) dan Fuzzy Logic Controller (FLC).

Penelitian ini bertujuan untuk mengimplementasi metode Fuzzy Logic Controller (FLC) untuk mengatur $\mathrm{pH}$ nutrisi pada sistem hidroponik NFT agar dapat menjaga kestabilan nilai $\mathrm{pH}$ nutrisi sebesar 5,5. Adapun sistem kontrol yang digunakan adalah Arduino Mega2560 dengan Analog pH Meter Kit sebagai input, serta solenoid valve sebagai aktuator pada sistem kontrol tersebut. Tanaman yang diatur tingkat $\mathrm{pH}$ nutrisinya pada sistem ini adalah selada (Luctuca Sativa L.).

\section{TINJAUAN PUSTAKA}

\subsection{Sistem Kontrol Hidroponik}

Sistem kontrol hidroponik bertujuan untuk mengatur pertumbuhan dari tanaman yang ditanam agar dapat tumbuh optimal sehingga didapat hasil yang maksimal. Hasil yang diharapkan dapat berupa buah dari tanaman berbuah ataupun daun dari tanaman jenis sayuran. Parameter yang dikontrol dapat berupa tingkat pencahayaan untuk membantu proses fotosintesis, konsentrasi kandungan nutrisi, kelembaban, suhu, atau pengaturan nilai $\mathrm{pH}$ nutrisi agar penyerapan nutrisi oleh akar bisa optimal.

Sistem otomatisasi pemeliharaan tanaman hidroponik untuk mengendalikan pemberian pupuk, pengaturan pompa air, dan pengaturan pemberian sinar matahari telah dikembangkan menggunakan mikrokontroler AT89S52 [6]. Sistem ini belum menerapkan pengaturan $\mathrm{pH}$ nutrisinya.

Beberapa metode kontrol juga telah digunakan untuk mengontrol pertumbuhan tanaman hidroponik. Kontrol PID (Proportional Integral Derivative) telah digunakan untuk mengontrol kadar $\mathrm{pH}$ pada sistem hidroponik stroberi [5]. Kontrol kadar pH dilakukan dengan mengendalikan kecepatan putaran pompa tangki berisi lauratan asam dan basa.

Sistem FLC juga telah digunakan untuk mengontrol nutrisi sistem hidroponik NFT seperti dijelaskan pada $[7,8,9]$. Sistem kontrol yang dibangun mengatur laju volume pemberian 8 tabung nutrisi melalui bukaan valve pada sistem hidroponik tanaman tomat [7]. Sistem pengaturan pada sistem ini mempengaruhi molaritas nutrisi yang diberikan pada tanaman sehingga diharapkan pertumbuhan tanaman bisa optimal. Pada [8], sistem kontrol fuzzy untuk menjaga $\mathrm{pH}$ larutan nutrisi pada sistem hidroponik NFT telah dimodelkan dan disimulasikan. Pada [9], FLC diimplementasikan untuk mengontrol Electrical Conductivity (EC) pada larutan nutrisi sistem hidroponik.

Simulasi pemodelan sistem NFT untuk mengatur $\mathrm{pH}$ pada budidaya sawi [10] juga telah dibuat menggunakan persamaan regrasi linier antara flow nutrisi terhadap $\mathrm{pH}$ dan $\mathrm{pH}$ terhadap tinggi tanaman, yang kemudian diintegrasikan dengan FLC menggunakan Simulink, MatLab.

\subsection{Sistem Nutrient Film Technique (NFT) dan Pengaturan pH Nutrisi}

Hidroponik NFT adalah teknik pemberian larutan nutrisi melalui aliran tersirkulasi yang sangat dangkal [2]. Air yang mengandung semua nutrisi terlarut tersebut diberikan secara terusmenerus selama 24 jam. Adapun kelebihan dari sistem ini yaitu suplai air, oksigen dan nutrisi tercukupi karena dilakukan secara terus-menerus.

Nutrisi yang diberikan pada tanaman erat kaitannya dengan $\mathrm{pH}$ air atau derajat keasaman air. Parameter $\mathrm{pH}$ nutrisi hidroponik sangat penting karena akan mempengaruhi ketersediaan dan penyerapan beberapa unsur atom 16 yang diperlukan untuk pertumbuhan tanaman. Penyerapan maksimum elemen ini ditemukan pada pembacaan $\mathrm{pH}$ 5,5 sampai 6. Ketika $\mathrm{pH}$ tersebut turun, maka ketersediaan unsur makro berkurang dan penyerapan nutrisi mikro dapat mencapai tingkat beracun. Menurut Erawati [10], kisaran $\mathrm{pH}$ yang baik antara 5,5 - 6,5 dan optimal sekitar 6. Lebih lanjut menurut Morgan 
[11], nilai $\mathrm{pH}$ untuk larutan hara pada budidaya selada hidroponik selada dipertahankan antara $5,6-6$. Oleh karena itu, pada penelitian ini nilai $\mathrm{pH}$ dipertahankan sebesar 5,5.

Penurunan dan peningkatan $\mathrm{pH}$ larutan nutrisi dapat dilakukan melalui penambahan asam $\left(\mathrm{HNO}_{3}, \mathrm{H}_{3} \mathrm{PO}_{4}\right.$ atau $\left.\mathrm{H}_{2} \mathrm{SO}_{4}\right)$ atau penambahan basa $(\mathrm{KOH})$ ke larutan nutrisi [2]. Pengaturan kadar $\mathrm{pH}$ pada penelitian ini dilakukan dengan menambahkan larutan asam sulfat $\left(\mathrm{H}_{2} \mathrm{SO}_{4}\right)$ selanjutnya disebut $\mathrm{pH}$, up agar nutrisi menjadi lebih asam. Demikian sebaliknya, digunakan larutan kalium hidroksida $(\mathrm{KOH})$, selanjutnya disebut $\mathrm{pH}$ down, agar nutrisi menjadi lebih basa.

\subsection{Sensor $\mathbf{p H}$}

Pengukuran $\mathrm{pH}$ dilakukan dengan menggunakan elektroda potensiometrik. Elektroda ini memonitor perubahan voltase yang disebabkan oleh perubahan aktivitas ion hidrogen $(\mathrm{H}+)$ dalam larutan. Elektroda $\mathrm{pH}$ yang paling modern terdiri dari kombinasi tunggal elektroda referensi (reference electrode) dan elektroda sensor (sensing electrode) yang lebih mudah dan lebih murah daripada elektroda tepisah. Keluaran dari $\mathrm{pH}$ meter sudah dikalibrasi dalam $\mathrm{mV}$ dan kondisi ideal dari elektroda $\mathrm{pH}$ pada suhu $25{ }^{\circ} \mathrm{C}$. Dengan memonitor perubahan tegangan yang disebabkan oleh perubahan aktifitas ion hidrogen $(\mathrm{H}+)$ dalam larutan maka $\mathrm{pH}$ larutan dapat diketahui.

\subsection{Fuzzy Logic Controller}

Fuzzy Logic Controller (FLC) merupakan metode pengontrol menggunakan prinsip pengambilan keputusan menggunakan logika fuzzy (Fuzzy Inference System). Metode ini telah banyak diterapkan diberbagai bidang karena kemudahan implementasinya, seperti pada bidang robotika contohnya pada [12, 13], atau pengaturan sistem tenaga listrik $[14,15]$. Sedangkan dalam bidang pertanian khususnya pada sistem hidroponik dapat ditemukan pada [7, 8 ,9].

Pada logika fuzzy yang dikenalkan oleh Lotfi Zadeh, berbeda dengan logika biasa atau tradisional dimana logika fuzzy dasarnya adalah kekaburan dan ketidakpastian [16]. Logika fuzzy merupakan cara untuk memetakan ruang masukan kedalam ruang keluaran. Karakteristik lain yang ada pada logika fuzzy adalah dapat dibangun berdasarkan pengalaman seorang ahli, dengan kata lain logika fuzzy dapat memformulasikan pengetahuan seorang ahli [16].

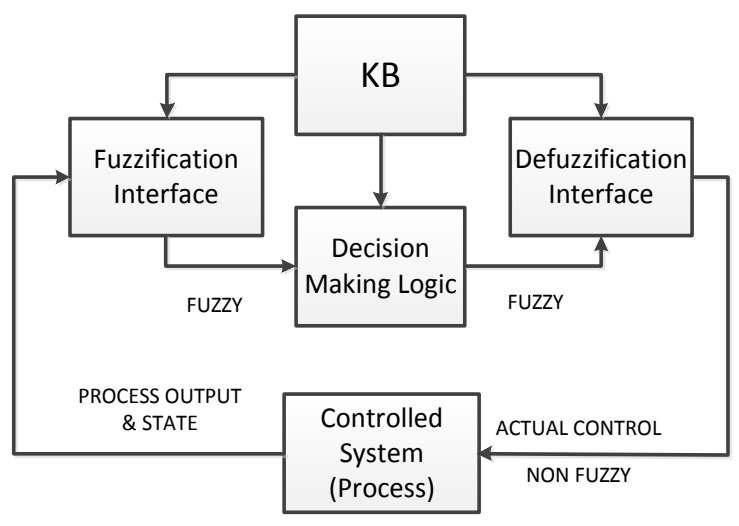

Gambar 1. Konfigurasi Dasar Fuzzy Logic Controller (FLC) [17]

Gambar 1 merupakan konfigurasi dasar sebuah sistem FLC yang terdiri dari empat komponen utama, yaitu: fuzzifikasi, Basis Pengetahuan/knowledge base (KB), logika pengambil keputusan (Decision Making Logic), dan defuzzifikasi [17].

1. Fuzzifikasi

Fuzzifikasi melibatkan fungsi berikut[17]: a) mengukur nilai variabel masukan, b) melakukan pemetaan skala yang memetakan rentang nilai masukan ke dalam semesta pembicaraan yang bersesuaian, c) melakukan fungsi fuzzifikasi yang mengkonversikan data masukan kedalam nilai linguistik yang sesuai yang bisa dipandang sebagai label dari himpunan fuzzy.

\section{Basis Pengetahuan}

Basis pengetahuan (Knowledge Base) terdiri dari pengetahuan tentang domain aplikasi dan kumpulan tujuan dari pengontrolan [17]. Disinilah perilaku dari kontroler dirumuskan agar tujuan pengontrolan bisa dicapai.

\section{Logika Pengambil Keputusan}

Bagian ini memiliki kemampuan untuk mensimulasikan model pengambilan keputusan manusia berdasarkan konsep fuzzy dan mengambil keputusan aksi kontrol fuzzy dengan menerapkan implikasi fuzzy dan penalaran basis aturan dalam logika fuzzy [17]. 


\section{Defuzzifikasi}

Defuzzifikasi melakukan pemetaan dari rentang nilai keluaran ke dalam semesta pembicaraan yang bersesuaian, dan proses ini menghasilkan nilai aksi kontrol non-fuzzy [17]. Pada penelitian ini proses defuzzifikasi menggunakan metode COA (Center of Area) yang dirumuskan seperti pada Persamaan 1 [18].

$$
z_{0}=\frac{\sum_{j=1}^{n} \mu\left(w_{j}\right) \cdot w_{j}}{\sum_{j=1}^{n} \mu\left(w_{j}\right)}
$$

\section{METODOLOGI}

Perancangan penelitian ini dibagi menjadi dua bagian utama yaitu perancangan perangkat keras dan perangkat lunak. Pada perancangan perangkat keras dimulai dengan pembuatan modul NFT, kemudian dibuat sistem kontrol elektronik berbasis mikrokontroler. Pada perancangan perangkat lunak, sistem kendai fuzzy dibuat menggunakan software Arduino.

\subsection{Perancangan Modul Hidroponik Nutrient Film Technique (NFT)}

Perancangan modul hidroponik Nutrient Film Technique (NFT) meliputi perancangan tangki nutrisi dan talang pertumbuhan tanaman hidroponik. Rancangan modul hidroponik Nutrient Film Technique (NFT) dapat dilihat pada Gambar 2.

Tangki nutrisi terbuat dari plastik jenis Poly Vinyl Chloride (PVC) dengan kapasitas penampungan sebanyak 30 liter air. Di dalam tangki tersebut terdapat sebuah pompa aquarium mini yang berdaya 15 watt. Di antara tangki nutrisi dan talang pertumbuhan tanaman hidroponik akan di desain sistem otomasi $\mathrm{pH}$ dan tabung modifikasi yang digunakan sebagai wadah cairan $\mathrm{pH}$ up dan $\mathrm{pH}$ down. Talang tersebut diposisikan pada arah vertikal dan dilubangi sebanyak 3 buah lubang berdiameter $25 \mathrm{~mm}$. Talang ini memiliki panjang $60 \mathrm{~cm}$ dengan tinggi $50 \mathrm{~cm}$. Jarak antar talang sebesar $10 \mathrm{~cm}$ dengan kemiringan talang sebesar $4 \mathrm{~cm}$. Hal ini bertujuan agar arus air dapat mengalir dengan lancar dengan kecepatan 1-2 liter / menit, sehingga tanaman tidak kekurangan nutrisi.

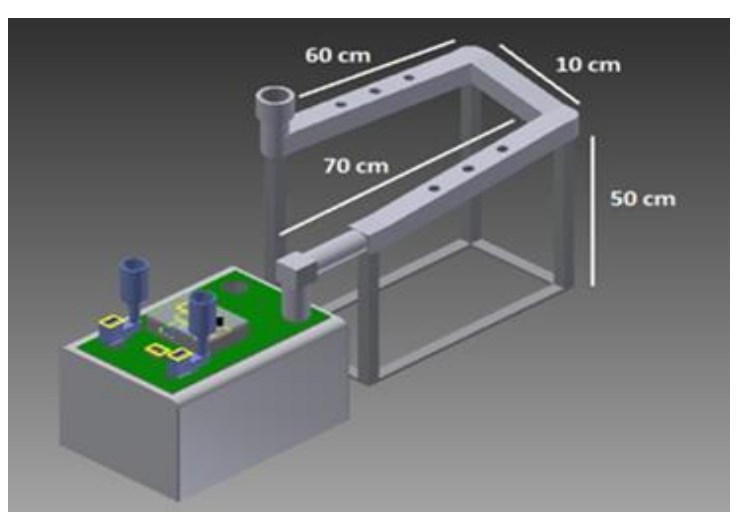

Gambar 2. Perancangan modul hidroponik Nutrient Film Technique (NFT)

\subsection{Perancangan Sistem Elektronik Kontrol pH Nutrisi Hidroponik}

Secara lengkap diagram blok sistem kontrol pH pada hidroponik NFT ditampilkan pada Gambar 3. Perangkat keras yang digunakan antara lain sensor analog pH SKU:SEN0161 untuk mengukur nilai $\mathrm{pH}$ dalam nutrisi, Liquid Crystal Display 16x2 yang berfungsi untuk memonitor nilai $\mathrm{pH}$ terukur, Arduino Mega2650, rangkaian penggerak (driver) solenoid dan dua buah $\mathrm{AC}$ solenoid valve yang berfungsi untuk mengatur aliran cairan $\mathrm{pH}$ up dan $\mathrm{pH}$ down.

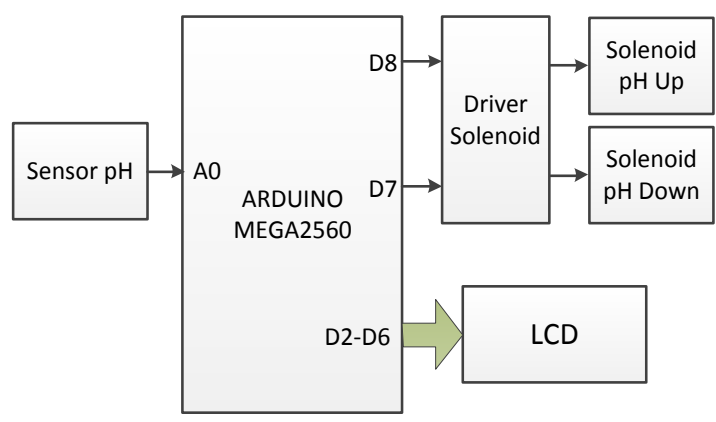

Gambar 3. Diagram Blok Sistem Kontrol pH pada Hidroponik NFT

\subsection{Driver AC Solenoid Valve}

Untuk mengatur aliran cairan $\mathrm{pH}$ up dan down digunakan solenoid valve yang akan terhubung dengan tabung $\mathrm{pH}$ up dan down. Untuk pengaturan dari on/off tersebut digunakan optocoupler MOC3021. Sementara itu untuk mengendalikan tegangan digunakan triac BT136 sebagai switching. Rangkaian dari pengaturan on/off dapat dilihat pada Gambar 4. 


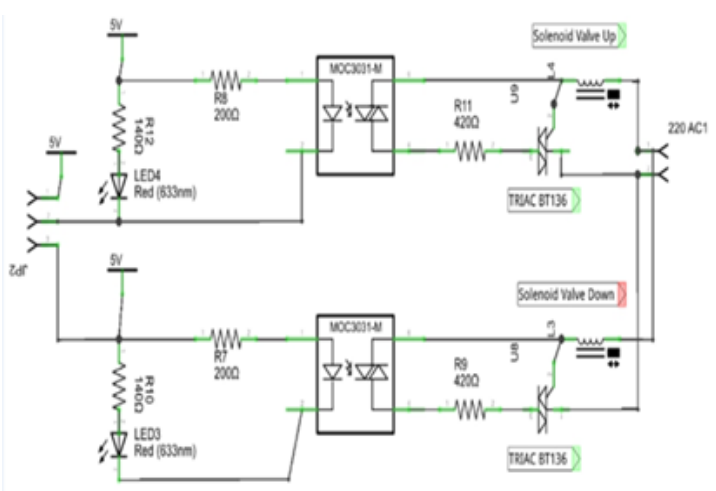

Gambar 4. Rangkaian Pengaturan On/Off Solenoid Valve

\subsection{Perancangan Sistem Fuzzy Logic Controller (FLC)}

Perancangan FLC dimulai dari merancang fungsi keanggotaan (membership function) dari masukan dan keluaran, kemudian dirancang basis aturan (Rule Base) dan fungsi defuzzifikasi. Sistem yang dirancang dalam penelitian ini mengacu pada Gambar 5. Hasil rancangan sistem diimplementasikan dalam bentuk bahasa pemrograman ke mikrokontroler ATMega2650 menggunakan program Arduino.

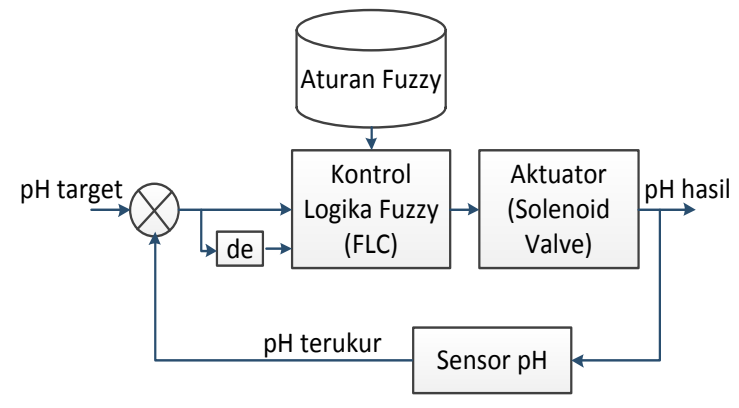

Gambar 5. Blok Diagram Fuzzy Logic Controller

Prinsip kerjanya adalah nilai input terdiri dari 2 yaitu error dan delta error dari pembacaan sensor $\mathrm{pH}$ yang akan dibandingkan dengan nilai set point sebesar 5,5. Kemudian nilai tersebut akan diolah oleh FLC.

Fungsi keanggotaan dari input dan output mengikuti Gambar 6, dimana setiap input dibagi menjadi 5 membership function yaitu Negatif Besar (NB), Negatif Kecil (NK), Zero (Z) atau Netral (N), Positif Kecil (PK) dan Positif Besar (PB). Nilai tersebut terbagi menjadi 3 rentang nilai yaitu negatif, nol dan positif. Hal ini didapat dari pengurangan set point terhadap nilai $\mathrm{pH}$ yang ditentukan oleh peneliti.

Untuk rule base yang diterapkan pada sistem ini mengikuti Tabel 1. Perancangan fungsi keanggotaan ouput terdiri dari durasi waktu yang berupa keluaran singleton yaitu Diam (0), Sedang (250), dan Lama (500). Satuan dari keluaran singleton tersebut dikonversikan ke dalam detik. Eksekusi masing-masing aturan diproses menggunakan fungsi implikasi MIN yang akan mengambil nilai paling minimal dari kedua masukan.

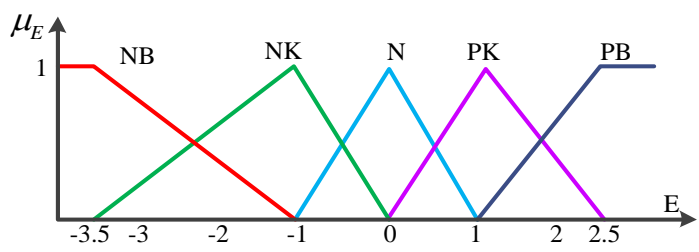

(a) Membership Function of Error

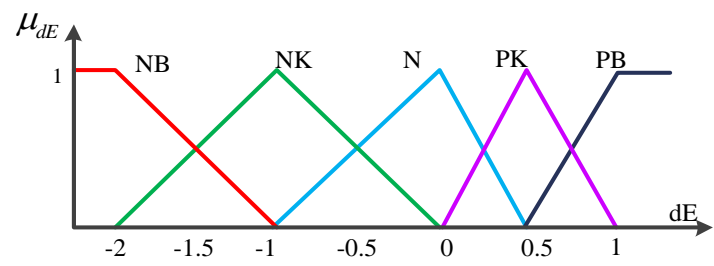

(b) Membership Function of Delta Error

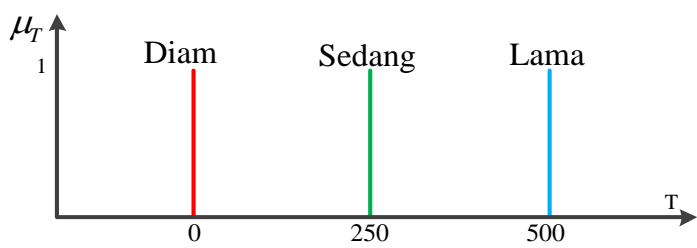

(c) Membership Function of Output

Gambar 6. Fungsi Keanggotaan Input dan Output (a) Error, (b) Delta Error, (c) Output

Tabel 1. Tabel Rule Base

\begin{tabular}{|c|c|c|c|c|c|}
\hline \multirow{2}{*}{$\Delta E$} & \multicolumn{2}{|c|}{$\begin{array}{c}\text { Valve } \mathrm{pH} \\
\text { Down ON }\end{array}$} & Off & \multicolumn{2}{c|}{ Valve $\mathrm{pH}$ Up } \\
\cline { 2 - 6 } & $\mathrm{NB}$ & $\mathrm{NK}$ & $\mathrm{N}$ & $\mathrm{PK}$ & $\mathrm{PB}$ \\
\hline NB & Lama & Sedang & Diam & Sedang & Lama \\
\hline NK & Lama & Sedang & Diam & Sedang & Lama \\
\hline $\mathrm{Z}$ & Lama & Sedang & Diam & Sedang & Lama \\
\hline PK & Lama & Sedang & Diam & Sedang & Lama \\
\hline PB & Lama & Sedang & Diam & Sedang & Lama \\
\hline
\end{tabular}




\subsection{Metode Pengujian}

Untuk pengujian akan diamati dan dibandingkan hasil respon sistem kendali FLC dengan menggunakan 25 aturan yang sesuai dengan rancangan Tabel 1 dan 15 aturan yang sesuai dengan Tabel 2. Semua 15 aturan tersebut diperoleh dengan menghilangkan aturan-aturan yang terdapat pada kolom dE Negatif Besar (NB) yang bernilai -2 dam Positif Besar (PB) yang bernilai 1. Nilai-nilai tersebut memiliki kemungkinan yang berpengaruh kecil terhadap plan.

Tabel 2. Rancangan 15 Aturan Fuzzy Logic Controller

\begin{tabular}{|c|c|c|c|c|c|}
\hline \multirow{2}{*}{$\Delta E$} & \multicolumn{2}{|c|}{$\begin{array}{c}\text { Valve pH Down } \\
\text { ON } \\
\end{array}$} & \multirow{2}{*}{$\frac{\text { Off }}{\mathrm{N}}$} & \multicolumn{2}{|c|}{$\begin{array}{c}\text { Valve pH Up } \\
\text { ON }\end{array}$} \\
\hline & NB & NK & & PK & PB \\
\hline NB & & & & & \\
\hline NK & Lama & Sedang & Diam & Sedang & Lama \\
\hline Z & Lama & Sedang & Diam & Sedang & Lama \\
\hline PK & Lama & Sedang & Diam & Sedang & Lama \\
\hline PB & & & & & \\
\hline
\end{tabular}

\section{HASIL DAN PEMBAHASAN}

Berdasarkan perancangan sistem yang gambarkan sebelumnya pada Gambar 3, maka dilakukan pengujian serta analisis terhadap sistem yang telah dirancang. Hal ini bertujuan untuk membuktikan apakah sistem yang diimplementasikan dapat mempertahankan nilai $\mathrm{pH}$ nutrisi sebesar 5,5, kemudian diamati juga respon FLC terhadap waktu. Perkembangan tanaman selada pada sistem NFT juga diamati pada pembahasan ini.

\subsection{Pengujian Sensor $\mathbf{p H}$}

Pengujian sensor $\mathrm{pH}$ dilakukan dengan membandingkan pembacaan sensor $\mathrm{pH}$ dengan nilai $\mathrm{pH}$ yang sebenarnya dengan menggunakan alat ukur $\mathrm{pH}$ meter. Cairan yang digunakan untuk pengujian terdiri dari berbagai jenis. Tabel 3 merupakan hasil perbandingan pengujian sensor $\mathrm{pH}$ dengan $\mathrm{pH}$ meter standar terhadap berbagai jenis cairan. Hasil perbandingan menunjukkan ada selisih rata-rata sebesar $6.58 \%$.
Tabel 3. Pengujian Sensor $\mathrm{pH}$

\begin{tabular}{|c|c|c|c|}
\hline Jenis Cairan & $\begin{array}{c}\mathrm{pH} \\
\text { Meter }\end{array}$ & $\begin{array}{c}\text { Sensor } \\
\mathrm{pH}\end{array}$ & $\begin{array}{c}\text { Error } \\
(\%)\end{array}$ \\
\hline pH Buffer 6.86 & 7 & 6,853 & 2,10 \\
\hline pH Buffer 4.00 & 4 & 3,673 & 8,18 \\
\hline Cuka & 2.5 & 1,913 & 23,48 \\
\hline Air Kran & 5.5 & 5,78 & 5,09 \\
\hline Sabun Cuci Piring & 4.5 & 4,1 & 8,89 \\
\hline Cairan Detergen & 9.7 & 9,72 & 0,21 \\
\hline Nutrisi Hidroponik & 5.6 & 5,38 & 3,93 \\
\hline Air Sabun & 7.6 & 7,54 & 0,79 \\
\hline \multicolumn{3}{|c|}{ Rata-Rata Error (\%) } & 6.58 \\
\hline
\end{tabular}

\subsection{Pengujian Sistem Kendali Fuzzy Logic Controller}

Pada pengujian ini masing-masing nilai $\mathrm{pH}$ akan diatur dengan nilai yang sama. Hasil pengujian respon akan dianalisa untuk mengetahui rise time, time settling dan error steady state yang dihasilkan dari sistem FLC yang diimplementasikan.

\subsubsection{Pengujian Fuzzy Logic Controller untuk Menaikkan pH}

Pengujian ini ditujukan untuk melihat performa FLC pada saat menaikkan nilai $\mathrm{pH}$ cairan nutrisi. Nilai awal $\mathrm{pH}$ dipilih dari 5,38 dan 3,27 untuk jumlah 25 aturan, sedangkan untuk 15 aturan dipilih yang nilai $\mathrm{pH}$ mendekati yaitu 5,23 dan 3,51.

Pada Gambar 7 terlihat bahwa pada waktu 856 milisecond terjadi penurunan pembacaan nilai sensor sebesar 4.78. Kemudian pada durasi ke 1381 hingga 1479 milisecond, pembacaan nilai $\mathrm{pH}$ bersifat stabil yaitu sebesar 5,49. Sistem berhasil mencapai nilai setpoint pada durasi waktu ke 1484 milisecond, namun mengalami penurunan kembali menjadi 5,49. Pada durasi ke 1483 milisecond hingga 1503 milisecond, respon sistem mengalami overshoot sebesar $1 \%-3 \%$. Respon kembali stabil berada di pembacaan $\mathrm{pH}$ sebesar 5,49 - 5,5 yaitu pada durasi waktu 1504 hingga 2000 milisecond.

Pada percobaan dengan 15 aturan sesuai Gambar 8 menunjukkan bahwa pada durasi ke 1560 hingga 1577 milisecond terjadi overshoot sebesar 4\% - 4,8 \%, dan kembali pada kondisi steady state pada nilai $\mathrm{pH}$ sebesar 5,49 hingga setpoint pada durasi ke 1577 milisecond sampai 1942 milisecond. Sedangkan pada durasi ke 1800 milisecond sampai 2000 milisecond, 
respon sistem kembali mengalami steady state dengan pembacaan nilai $\mathrm{pH}$ sebesar 5,49-5,51.

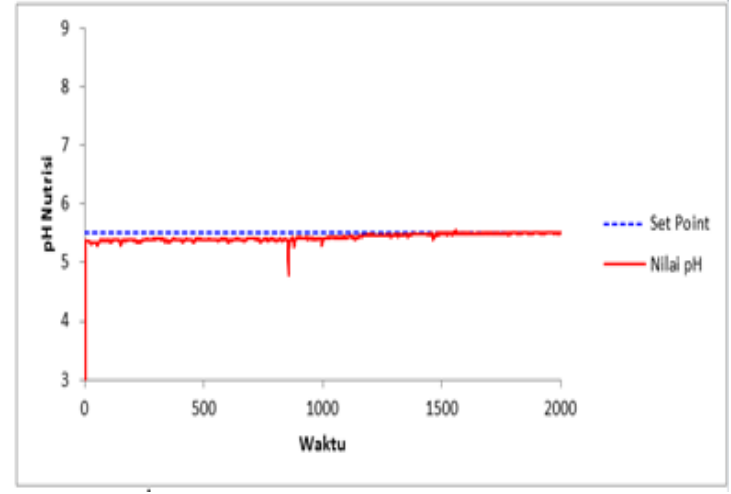

Gambar 7. Grafik Respon Perubahan pH 5,38 dengan 25 aturan

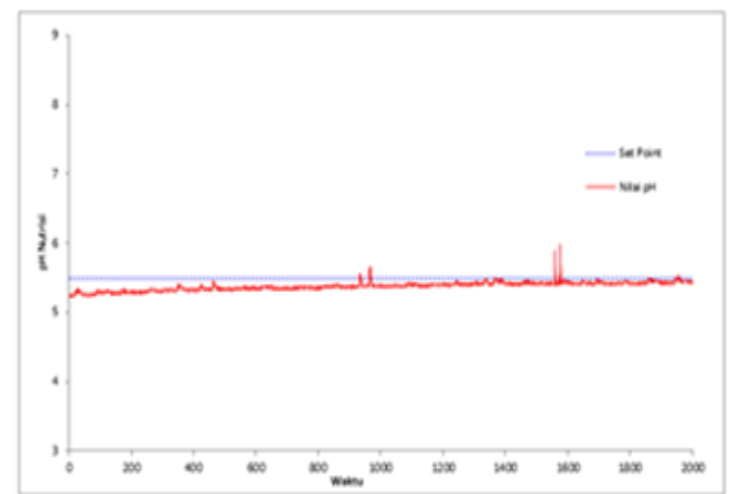

Gambar 8. Grafik Respon Perubahan pH 5,23 dengan 15 aturan

Pengujian selanjutnya yaitu mengamati perubahan nilai $\mathrm{pH}$ yang memiliki selisih lebih besar dari setpoint. Nilai $\mathrm{pH}$ yang digunakan sebagai pengujian merupakan nilai $\mathrm{pH}$ yang memiliki kategori error Positif Besar. Sesuai Gambar 9, nilai $\mathrm{pH}$ sebesar 3,27 dan 3,51 merupakan kondisi $\mathrm{pH}$ yang sangat asam dan masuk kedalam kategori error Positif Besar. Respon mengalami kondisi steady state pada nilai 5,49 ketika berada pada durasi ke 5530 milisecond. Ketika berada di waktu ke 5960 milisecond, respon berhasil mencapai setpoint selama beberapa millisecond namun kemudian kembali ke posisi steady state, hingga akhirnya mengalami overshoot sebesar $1 \%$ pada waktu ke 6200 milisecond. Selain itu respon mengalami steady state secara terus-menerus hingga kondisi sistem dalam keadaan off.

Sesuai Gambar 10, ketika berada di waktu ke 3000 milisecond, respon mengalami kondisi steady state pada nilai $\mathrm{pH} 5,48$ hingga 5,49. Kemudian berhasil mencapai setpoint pada durasi waktu ke 3129 milisecond, dan kembali turun pada nilai 5,49 hingga beberapa kali mengalami overshoot sebesar $1 \%$ pada waktu 3130 milisecond.

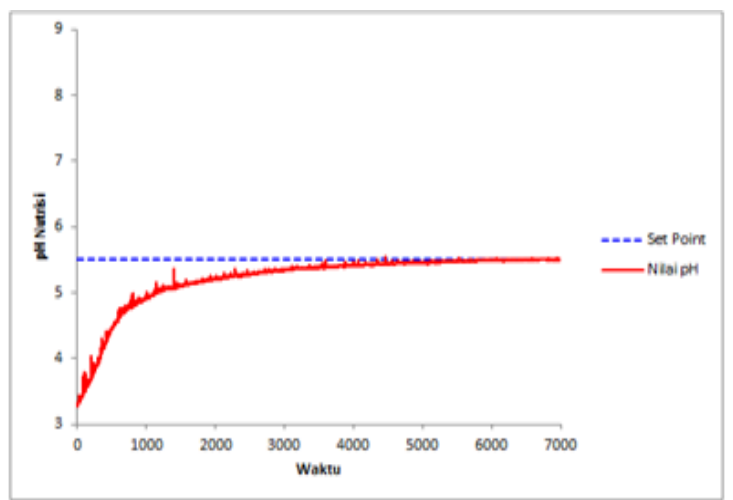

Gambar 9. Respon Perubahan pH 3,27 dengan 25 aturan

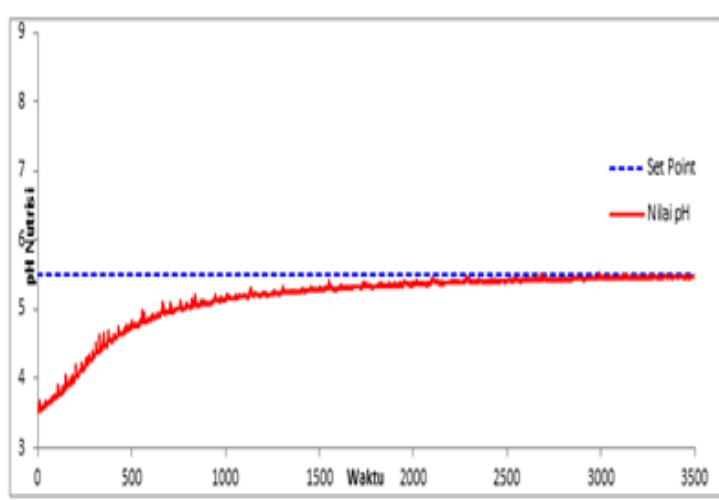

Gambar 10. Respon Perubahan pH 3,51 dengan 15 aturan

Tabel 5 merupakan ringkasan dari hasil pengujian yang telah dijelaskan diatas. Dengan 25 aturan, nilai rise time pada kategori error Positif Kecil lebih cepat responnya dibandingkan dengan nilai rise time pada kategori error Positif Besar. Hal ini disebabkan karena nilai error Positif Kecil lebih mendekati nilai error kategori Netral, atau dengan kata lain nilai pH mendekati setpoint sehingga FLC tidak memerlukan proses yang lama untuk mengambil keputusan. Hal ini juga berlaku pada sistem dengan 15 aturan, hanya saja respon waktu yang diperlukan sistem dengan 15 aturan untuk mencapai rise time lebih cepat durasinya yaitu 
setengah dari durasi pencapaian sistem dengan 25 aturan. Meskipun demikian, FLC dengan 15 aturan memiliki kekurangan yaitu maximum overshoot yang terjadi lebih besar dibandingkan dengan maximum overshoot sistem dengan 25 aturan.

Tabel 5. Rangkuman Hasil Pengujian FLC Untuk Menaikkan $\mathrm{pH}$

\begin{tabular}{|c|c|c|c|c|}
\hline \multirow{2}{*}{ Respon Sistem } & \multicolumn{2}{|c|}{ FLC 25 Aturan } & \multicolumn{2}{c|}{ FLC 15 Aturan } \\
\cline { 2 - 5 } & \multicolumn{2}{|c|}{$\mathrm{pH}$} & \multicolumn{2}{c|}{$\mathrm{pH}$} \\
\cline { 2 - 5 } & 5,38 & 3,27 & 5,23 & 3,51 \\
\hline Rise Time & $\begin{array}{c}886 \\
\mathrm{~ms}\end{array}$ & $\begin{array}{c}1200 \\
\mathrm{~ms}\end{array}$ & $\begin{array}{c}424 \\
\mathrm{~ms}\end{array}$ & $\begin{array}{c}500 \\
\mathrm{~ms}\end{array}$ \\
\hline Steady State & $\begin{array}{c}1381 \\
\mathrm{~ms}\end{array}$ & $\begin{array}{c}5350 \\
\mathrm{~ms}\end{array}$ & $\begin{array}{c}1577 \\
\mathrm{~ms}\end{array}$ & $\begin{array}{c}3000 \\
\mathrm{~ms}\end{array}$ \\
\hline Max Overshoot & $3 \%$ & $1 \%$ & $4,8 \%$ & $1 \%$ \\
\hline
\end{tabular}

\subsubsection{Pengujian Fuzzy Logic Controller} untuk Menurunkan pH

Dari hasil pengamatan, terlihat bahwa untuk menurunkan $\mathrm{pH}$ dengan 15 aturan, respon yang terjadi tidak stabil dan juga memiliki error steady state. Hal ini terlihat pada saat sistem menurunkan $\mathrm{pH} 7$ ke setpoint. Dari Gambar 11, terlihat bahwa sistem mengalami penurunan yang signifikan pada waktu ke 2237 milisecond dengan nilai sebesar 6,45. Sistem juga mengalami respon steady state pada waktu ke 3000 milisecond, namun mengalami penurunan yang drastis dengan error steady state sebesar 5 $\%-25 \%$ dari durasi 3400 milisecond hingga 5900 milisecond.

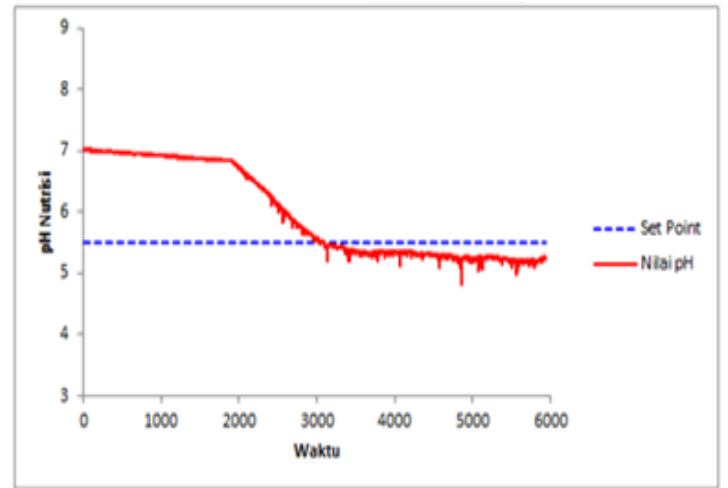

Gambar 11. Grafik Respon Penurunan pH 7 dengan 25 aturan

Sedangkan pada Gambar 12 terlihat bahwa respon mengalami penurunan yang stabil dari waktu 200 milisecond hingga 800 milisecond. Namun memberikan respon naik turun dalam durasi waktu yang lama yaitu pada waktu ke 2000 milisecond hingga 8000 milisecond. Selanjutnya kembali stabil pada waktu ke 8400 milisecond hingga 15200 milisecond dan kembali berosilasi hingga waktu ke 18400 milisecond.

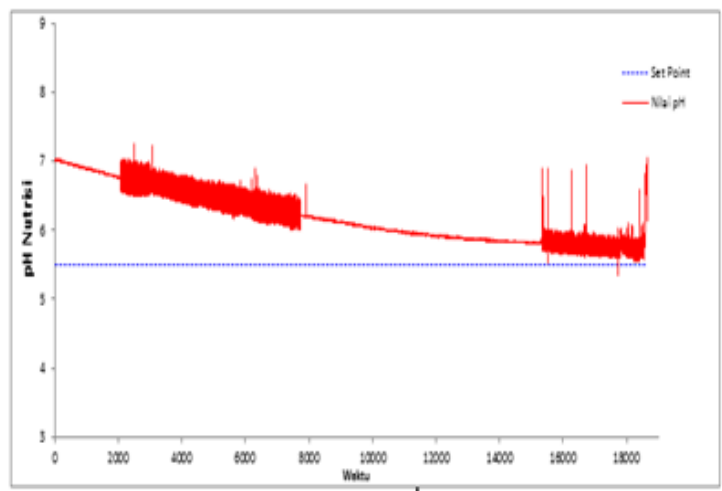

Gambar 12. Grafik Respon Penurunan pH 7 dengan 15 Aturan

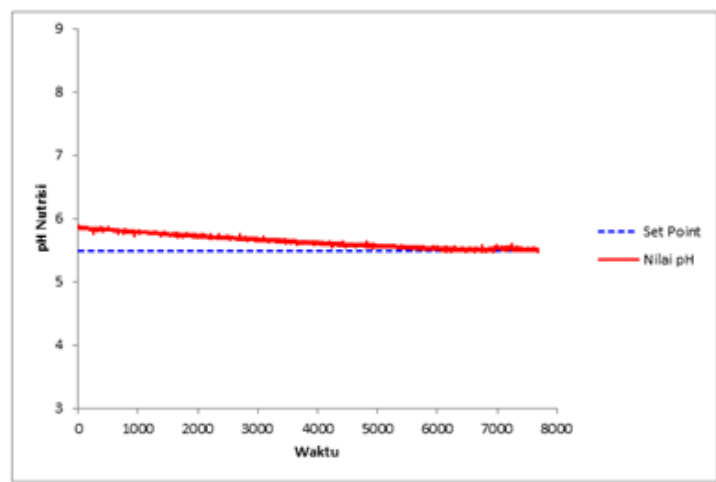

Gambar 13. Grafik Respon Penurunan pH 5.85 dengan 25 Aturan

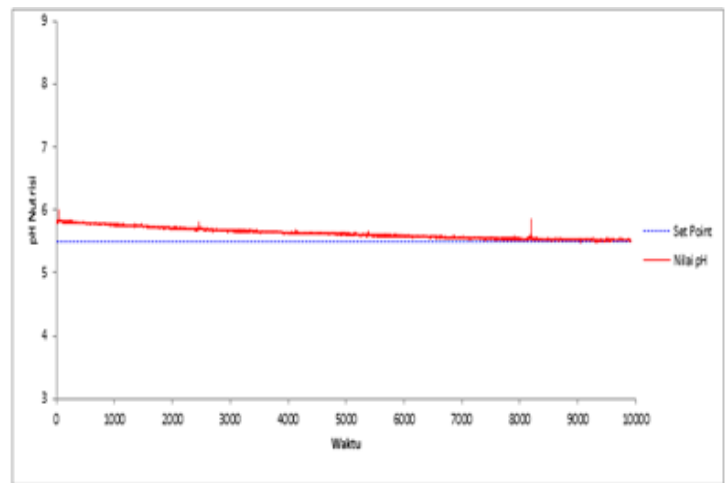

Gambar 14. Grafik Respon Penurunan pH 5,85 dengan 15 Aturan 
Pada percobaan selanjutnya, sesuai dengan Gambar 13 dan Gambar 14 terlihat bahwa terlihat bahwa penurunan $\mathrm{pH}$ dengan 25 aturan memiliki time settling yang lebih cepat yaitu 6500 milisecond dibandingkan dengan yang menggunakan 15 aturan yang mencapai steady state pada waktu 8700 milisecond.

Keseluruhan hasil pengamatan respon sistem pada Gambar 11 - Gambar 14. dapat dirangkum pada Tabel 6. Dari keseluruhan pengamatan yang dilakukan untuk menurunkan dan menaikkan $\mathrm{pH}$, didapat bahwa sistem bekerja lebih baik ketika menggunakan 25 aturan FLC. Hal ini dibuktikan karena maximum overshoot yang dihasilkan lebih kecil daripada menggunakan 15 aturan. Hal ini disebabkan seluruh kategori membership function memiliki aturan yang jelas untuk mengambil keputusan. Sementara ketika menggunakan 15 aturan, ada beberapa kategori input yang tidak memiliki aturan sehingga menyebabkan sistem tidak dapat mengambil keputusan hingga berdampak pada hasil respon yang berosilasi dan tidak stabil.

Dari Tabel 6, terlihat bahwa nilai rise time dan maximum overshoot berbanding terbalik yaitu semakin cepat nilai rise time maka akan semakin besar nilai overshoot. Namun semakin lama nilai rise time maka akan semakin kecil nilai overshoot. Hal ini dipengaruhi oleh tidak adanya aturan yang mengatur jika nilai error dalam Positif Besar dan Delta error dalam kategori Negatif Besar, sehingga respon menjadi tidak stabil.

Tabel 6. Hasil Pengujian Fuzzy Logic Controller Untuk Menurunkan pH

\begin{tabular}{|c|c|c|c|c|}
\hline \multirow{2}{*}{$\begin{array}{c}\text { Respon } \\
\text { Sistem }\end{array}$} & \multicolumn{2}{|c|}{ FLC 25 Aturan } & \multicolumn{2}{c|}{ FLC 15 Aturan } \\
\cline { 2 - 5 } & \multicolumn{2}{|c|}{$\mathrm{pH}$} & \multicolumn{2}{c|}{$\mathrm{pH}$} \\
\cline { 2 - 5 } Rise Time & $\begin{array}{c}5,85 \\
\begin{array}{c}2000 \\
\mathrm{~ms}\end{array}\end{array}$ & $\begin{array}{c}2237 \\
\mathrm{~ms}\end{array}$ & $\begin{array}{c}5400 \\
\mathrm{~ms}\end{array}$ & $\begin{array}{c}200 \\
\mathrm{~ms}\end{array}$ \\
\hline Time Settling & $\begin{array}{c}6500 \\
\mathrm{~ms}\end{array}$ & $\begin{array}{c}3000 \\
\mathrm{~ms}\end{array}$ & $\begin{array}{c}8700 \\
\mathrm{~ms}\end{array}$ & Osilasi \\
\hline $\begin{array}{c}\text { Max } \\
\text { Overshoot }\end{array}$ & $4 \%$ & $25 \%$ & $8 \%$ & $100 \%$ \\
\hline
\end{tabular}

\subsection{Hasil Pengamatan Respon Pertumbuhan Selada}

Pada bagian ini dilihat respon pertumbuhan 6 buah selada selama 20 - 60 hari. Adapun hasil pengamatannya ditampilkan pada Gambar 15 dan Gambar 16. Pada usia 20 - 49 hari, hidroponik NFT aktif dengan mengabaikan sistem kendali $\mathrm{pH}$. Kemudian pada usia 46-50 hari, hidroponik NFT aktif dengan menggunakan sistem kendali $\mathrm{pH}$. Modul Hidroponik NFT tersebut diletakkan secara outdoor namun diberi atap dengan suhu $30-33$ derajat Celcius.

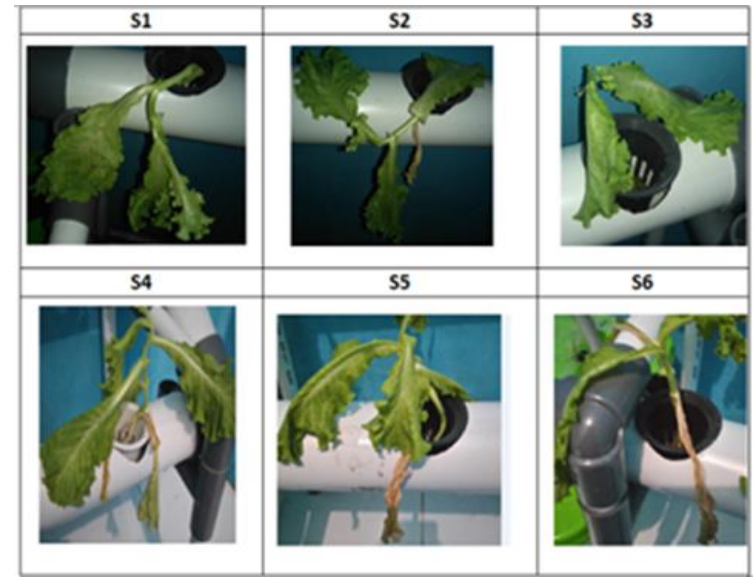

Gambar 15. Pertumbuhan 6 buah Selada dengan $\mathrm{pH}$ yang Tidak Stabil

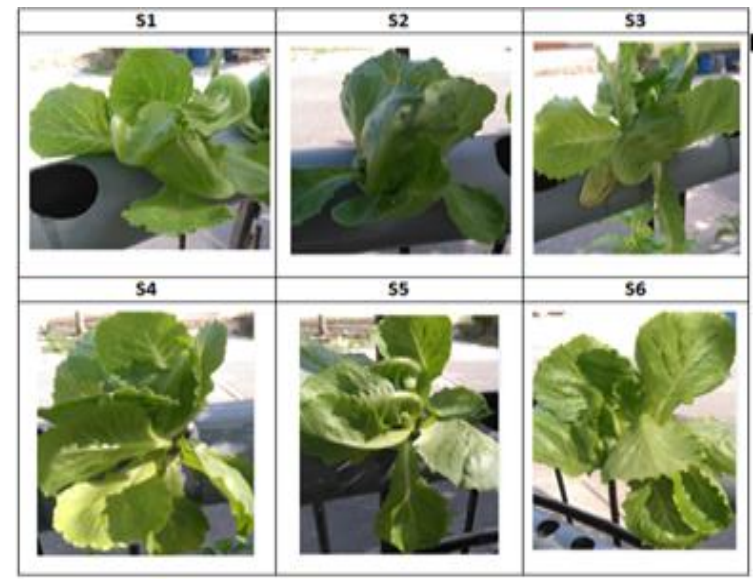

Gambar 16. Pertumbuhan 6 buah Selada dengan pH yang Stabil

Secara detail perkembangan selada tanpa sistem kontrol fuzzy dan dengan sistem kontrol fuzzy dapat dilihat pada Tabel 7 dan Tabel 8 . Dari hasil pengamatan didapat bahwa perbedaan $\mathrm{pH}$ berpengaruh terhadap tinggi tanaman bersifat stabil, artinya walaupun $\mathrm{pH}$ berubah-ubah tanaman tetap mengalami pertumbuhan. Namun, perbedaan $\mathrm{pH}$ lebih berdampak pada pertumbuhan jumlah daun dan kondisi daun 
selada. Beberapa daun selada mengalami kerontokan dan menguning ketika $\mathrm{pH}$ berubahubah sehingga daun tersebut harus dipotong agar tidak menular ke daun yang lain.

Dari data tersebut, didapat tinggi maksimal dari Selada yaitu sebesar $20 \mathrm{~cm}$ dengan jumlah daun yang tumbuh maksimal pada umur 54 hari sebanyak 7 helai daun. mampu mempertahankan $\mathrm{pH}$ sebesar 5,5 dengan hasil pertumbuhan selada setinggi $20 \mathrm{~cm}$ dan banyak daun 7 helai selama 54 hari.

2. Hasil respon terbaik dari implementasi Fuzzy Logic Controller terdapat pada sistem yang memiliki 25 aturan dengan

Tabel 7. Respon Pertumbuhan Selada Tanpa Sistem Kontrol pH

\begin{tabular}{|c|c|c|c|c|c|c|c|c|c|c|c|c|c|c|c|}
\hline \multirow{2}{*}{ No } & \multirow{2}{*}{ Tanggal/jam } & \multirow{2}{*}{$\begin{array}{c}\text { Umur } \\
\text { Selada }\end{array}$} & \multirow{2}{*}{$\mathrm{pH}$} & \multicolumn{6}{|c|}{ Jumlah Daun(helai) } & \multicolumn{6}{|c|}{ Tinggi Selada $(\mathrm{cm})$} \\
\hline & & & & S1 & $\mathrm{S} 2$ & S3 & S4 & S5 & S6 & $\mathrm{S} 1$ & S2 & S3 & S4 & S5 & S6 \\
\hline 1 & 20 Jan 10.30 & 20 Hari & 6,2 & 4 & 4 & 4 & 4 & 4 & 4 & 4,5 & 6 & 5 & 4,5 & 4 & 1,5 \\
\hline 2 & $21 \mathrm{Jan} 07.15$ & 21 Hari & 6,4 & 5 & 5 & 5 & 4 & 5 & 4 & 6 & 6,5 & 5,5 & 5 & 6 & 4,5 \\
\hline 3 & 23 Jan 11.42 & 23 Hari & 6,1 & 5 & 5 & 5 & 5 & 5 & 5 & 7 & 8 & 7 & 6 & 8 & 5 \\
\hline 4 & 25 Jan 05.30 & 24 Hari & 5,9 & 6 & 6 & 6 & 5 & 5 & 5 & 8 & 8,5 & 7,5 & 7,5 & 8,5 & 7 \\
\hline 5 & 26 Jan 11.45 & 25 Hari & 5,9 & 6 & 6 & 6 & 5 & 5 & 5 & 10 & 9,5 & 9,5 & 8,5 & 9 & 9 \\
\hline 6 & 27 Jan 10.55 & 26 Hari & 5,8 & 6 & 6 & 6 & 6 & 5 & 6 & 10,5 & 10 & 9,5 & 9 & 9,5 & 10 \\
\hline 7 & 9 Feb 05.30 & 40 Hari & 5,6 & 5 & 5 & 6 & 6 & 5 & 6 & 11 & 10 & 10 & 9,5 & 10 & 10 \\
\hline 8 & 10 Feb 10.00 & 41 Hari & 5,5 & 5 & 5 & 7 & 6 & 5 & 6 & 12 & 12 & 11 & 10 & 11 & 11 \\
\hline 9 & 11 Feb 11.45 & 42 Hari & 5,6 & 5 & 4 & 6 & 6 & 6 & 5 & 13 & 13 & 12,5 & 11,5 & 12 & 12 \\
\hline 10 & 12 Feb 08.00 & 43 Hari & 5,7 & 5 & 4 & 6 & 6 & 5 & 6 & 13 & 13 & 12,5 & 12 & 12,5 & 12 \\
\hline
\end{tabular}

Tabel 8. Respon Pertumbuhan Selada dengan Sistem Kontrol pH

\begin{tabular}{|c|c|c|c|c|c|c|c|c|c|c|c|c|c|c|c|}
\hline \multirow{2}{*}{ No } & \multirow{2}{*}{ Tanggal/jam } & \multirow{2}{*}{$\begin{array}{l}\text { Umur } \\
\text { Selada }\end{array}$} & \multirow{2}{*}{$\mathrm{pH}$} & \multicolumn{6}{|c|}{ Jumlah Daun (helai) } & \multicolumn{6}{|c|}{ Tinggi Selada $(\mathrm{cm})$} \\
\hline & & & & $\mathrm{S} 1$ & S2 & S3 & S4 & S5 & S6 & $\mathrm{S} 1$ & S2 & S3 & S4 & S5 & S6 \\
\hline 1 & 18 Feb 08.00 & 49 Hari & 5,5 & 6 & 4 & 5 & 6 & 6 & 5 & 18 & 18 & 18 & 17 & 18 & 17 \\
\hline 2 & 19 Feb 08.00 & 50 Hari & 5,5 & 6 & 4 & 5 & 7 & 6 & 5 & 18 & 18,5 & 18 & 17,5 & 18 & 17,5 \\
\hline 3 & $20 \mathrm{Feb} 08.00$ & 51 Hari & 5,5 & 6 & 4 & 5 & 7 & 6 & 5 & 19 & 19 & 18,5 & 18 & 18,5 & 18,5 \\
\hline 4 & $21 \mathrm{Feb} 08.00$ & 52 Hari & 5,5 & 6 & 5 & 5 & 7 & 6 & 5 & 20 & 20 & 19 & 19 & 19 & 19,5 \\
\hline 5 & 22 Feb 08.00 & 53 Hari & 5,5 & 6 & 5 & 5 & 7 & 6 & 5 & 20 & 20 & 19 & 19 & 19 & 19,5 \\
\hline 6 & $23 \mathrm{Feb} 08.00$ & 54 Hari & 5,5 & 6 & 5 & 5 & 7 & 6 & 5 & 20 & 20 & 19,5 & 19,5 & 20 & 20 \\
\hline
\end{tabular}

\section{KESIMPULAN}

Adapun kesimpulan yang dapat dirangkum dari hasil dan analisa data yang telah dilakukan antara lain :

1. Penelitian ini berhasil merealisasikan rancangan sistem kontrol $\mathrm{pH}$ nutrisi hidroponik secara otomatis menggunakan 2 buah aktuator berupa AC solenoid valve dan input berupa sensor analog $\mathrm{pH}$ SKU:SEN0161. Selain itu pula, metode Fuzzy Logic Controller yang diimplementasikan pada rancangan tersebut rise time 1200 milisecond dan time settling pada waktu ke 5530 milisecond untuk menaikkan $\mathrm{pH}$. Sedangkan untuk menurunkan $\mathrm{pH}$, rise time diperoleh pada waktu 2000 milisecond dan time settling pada waktu 3000 milisecond.

\section{DAFTAR PUSTAKA}

[1] Chadirin, Yudi. Pelatihan Aplikasi Teknologi Hidroponik Untuk Pengembangan Agribisnis Perkotaan. Pusat Pengkajian Dan Penerapan Ilmu 
Teknik Untuk Pertanian Tropika (CREATA) Lembaga Penelitian- Institut Pertanian Bogor. Bogor (2001).

[2] Indrawati, Ratna; Didik Indradewa; Sri Nuryani Hidayah Utami. "Pengaruh Komposisi Media dan Kadar Nutrisi Hidroponik terhadap Pertumbuhan dan Hasil Tomat (Lycopersicon esculentum Mill.)", Vegetalika, Vol. 1 No.3, Universitas Gajah Mada, 2012.

[3] http://hidroponiq.com/2015/05/ph-swingdampak-dan-penyebabnya/ , Diakses tanggal 12 Nopember 2015.

[4] Suhardiyanto, Herry. "Teknologi Hidroponik untuk Budidaya Tanaman". http://repository.ipb.ac.id/bitstream/handl e/123456789/13459/4 teknologi hidropo nik_utk_budidya_tanaman_herysuhar.pdf,. Diakses tanggal 11 Nopember 2015.

[5] Kustanti, Ika; Muslim M. A.; Yudaningtiyas, Erni. "Pengendalian Kadar Keasaman (pH) Pada Sistem Hidroponik Stroberi Menggunakan Kontroler PID Berbasis Arduino Uno", Jurnal Mahasiswa TEUB Vol 1, No 1, 2014.

[6] Utama, Hadian Satri; Sani M.Isa, Arie Indra Gunawan. "Perancangan dan Implementasi Sistem Otomatisasi Pemeliharaan Tanaman Hidroponik", Jurnal Teknik Elektro TESLA Vol.8 No. 1, 1-4, Maret 2006.

[7] Suprijadi; N.Nuraini; M. Yusuf. "Sistem Kontrol Nutrisi Hidroponik dengan menggunakan Logika Fuzzy", JOKI, vol.1, no.1, pp. 49 - 56, 2009.

[8] Hariyadi, Agung Dian. Cordova, Hendra. "Perancangan Kontrol pH Hidroponik Sistem NTF Berbasis Fuzzy Logic". Prosiding Seminar Nasional Teknik Fisika (SNFT 10), Surabaya. ISSN 2087-3433, 2010.

[9] Ibrahim, Muhammad Naufal Rauf; Mohamad Solahudin, Slamet Widodo; "Control System for Nutrient Solution of Nutrient Film Technique Using Fuzzy
Logic", TELKOMNIKA, Vol. 13, No. 4, pp. 1281 1288, Desember 2015.

[10] Erawati, Tina. "Pengaruh Sistem Pemberian Air Mengalir Metode NFT dan DFT Terhadap Pertumbuhan Tanaman Sawi Brassica Juncca dan Efisiensi Penggunaan Air dengan Menggunakan Larutan Nutrisi Setelah Panen ke-2.”, FTP Universitas Brawijaya, Malang. 2004.

[11] Morgan, Lynette. "Hydroponic Lectuce Production". Casper Publications Pty, Ltd.Narrabeen, Australia. 1999.

[12] Yulianto, Andik; Hadi Puspo Handoyo. "Penerapan Behavior-Based Control dan Fuzzy Logic Controller pada Sistem Navigasi Robot Soccer". CENTRE, Civil and Electrical Engineering Journal,Vol.7 No.1, pp.16-23, 2012.

[13] Pambudi, Wahyu Setyo; "Rancang Bangun 3 Wheels Omni-Directional Mobile Robot Menggunakan Sensor Position Sensitive Device (PSD) Serta Sensor Vision Dengan Metode Kendali Fuzzy Logic Controller (FLC) Untuk Menghindari Halangan", Proceeding Seminar Seminar Nasional Teknologi Informasi \& Komunikasi Terapan 2011 (Semantik 2011), UDINUS, 16 April 2011.

[14] Pamuji, Feby Agung; Soedibyo. "Desain Kontrol Multi -Input DC-DC Converter Sistem Hibrid Turbin Angin Dan Sel Surya Menggunakan Kontrol Fuzzy Logic Untuk Tegangan Rendah", Jurnal Nasional Teknik Elektro (JNTE) Vol.4 No.2, pp. 220-226, September 2015.

[15] Cahayahati; Syafii; Ija Darmana; Zulwisli. "Pengembangan Sistem Proteksi Digital Arus Lebih Berbasis Logika Fuzzy Sebagai Pengaman PLTMH", Jurnal Nasional Teknik Elektro (JNTE) Vol.2 No.2, pp. 1-7, September 2013.

[16] Naeeni, A.F. "Advanced Multi-Agent Fuzzy Reinforcement Learning” Master Thesis Computer Engineering, Computer 
Science Department, Dalarna University, Sweden. 2004.

[17] Lee, Chuen Chien, "Fuzzy Logic in Control Systems: Fuzzy Logic Controller - Part 1", IEEE Transactions on Systems, Man, Cybernatics, Vol.20, No.2, March/April, 1990.

[18] Lee, Chuen Chien, "Fuzzy Logic in Control Systems: Fuzzy Logic Controller - Part 2", IEEE Transactions on Systems, Man, Cybernatics, Vol.20, No.2, March/April, 1990.

\section{Biodata Penulis}

Dian Pancawati, lahir di PontianakKalimantan Barat. Penulis melanjutkan pendidikan Strata 1 di Teknik Elektro Universitas Internasional Batam pada tahun 2012. Penulis merupakan salah satu mahasiswa penerima Beasiswa Unggulan Biro Perencanaan dan Kerjasama Luar Negeri Kementrian Pendidikan dan Kebudayaan Indonesia (BPKL Kemdikbud) periode 2012-2016. Penulis pernah meraih pendanaan Program Kreativitas Mahasiswa bidang Karsa Cipta (PKM-KC) DIKTI untuk 2 buah proposal pada tahun 2012.

Andik Yulianto, lahir di Bojonegoro 1981. Telah menyelesaikan pendidikan S1 di Teknik Elektro Institut Teknologi Nasional Malang tahun 2005, kemudian menyelesaikan pendidikan S2 di jurusan Teknik Pengaturan di Institut Teknologi Sepuluh Nopember Surabaya tahun 2012. Saat ini aktif mengajar dan meneliti di Program Studi Teknik Elektro, Fakultas Teknologi Industri Universitas Internasional Batam. Bidang peminatannya adalah Teknik Kontrol dan Sistem Cerdas. Bisa dihubungi di andik@uib.ac.id. 